\title{
Non-destructive testing evaluation of low velocity impact damage in carbon fiber- reinforced laminated composites
}

\author{
M. A. Perez ${ }^{1}$, L. Gil ${ }^{1}$, S. Oller ${ }^{2}$ \\ ${ }^{I}$ Strength of Material and Structures Department, Technical University of Catalonia (Barcelona-Tech), \\ Laboratory for the Technological Innovation of Structures and Materials (LITEM), Terrassa, Barcelona, Spain. \\ Phone: +34937398 727,Fax: +34937398 994; e-mail: marco.antonio.perez@upc.edu, lluis.gil@upc.edu \\ ${ }^{2}$ Strength of Material and Structures Department, Technical University of Catalonia (Barcelona-Tech), \\ International Center for Numerical Methods in Engineering (CIMNE), Barcelona, Spain. \\ Phone: +34934017 401; e-mail: sergio.oller@upc.edu \\ crossref http://dx.doi.org/10.5755/j01.u.66.2.526
}

\begin{abstract}
Fiber-reinforced laminated composite materials are widely used in aircraft, modern vehicles and light-weight structures. With their high elastic modulus, high strength, and capability of being tailored for a several applications, these materials offer definite advantages compared to more traditional structural materials. However, their behavior under impact is of concern since those events may occur during manufacturing, normal operation or maintenance. The situation is critical for impacts that induce significant internal damage undetectable by visual inspection, which causes large reductions on the strength and stability of the structure. New standardized tests to assess the impact tolerance (ASTM D7136 and D7137) lose some of its appeal by its destructive nature as well as costs involved. Nondestructive techniques such as ultrasonic phased array or experimental modal analysis can be complementary in the evaluation of damage and structural integrity. The results of both destructive and non-destructive experiments carried out on forty-eight composite specimens are presented. A good correlation between incident impact energy and delaminated area as well as variation of eigenfrequencies is noticed. This study does not only provide a better understanding of the impact phenomenon but can also help in design and implementation of new test procedures for structural assessment.

Keywords: carbon fiber composite, low velocity impact, damage detection, non-destructive testing, modal analysis, and ultrasound phased array.
\end{abstract}

\section{Introduction}

The dropped tool on an aircraft wing during manufacture, maintenance activities or objects hitting during take-off or landing operations, can be examples of composite structures undergoing out-of-plane impacts. Impacts that do not result in complete penetration of the laminated can cause a barely visible internal damage capable of significantly reducing residual performance of a composite structure [1-3]. The material's relatively poor impact damage tolerance is mainly due to their low transverse and interlaminar shear strength, a laminar construction to compensate the anisotropic nature of plies and the lack of plastic deformation [4]. Experimental studies consistently indicate that induced impact damage consists of delaminations (the debonding between stackable sheets), matrix cracking and fiber failures [5]. While fiber fractures influence the residual tensile strength, delaminations are of most concern since significantly reducing the compression strength of the laminated.

During the last decades a significant research effort has been devoted to the study of impact behavior of composites. Several researchers [6- 9] have addressed the problem by examining the material's characteristics and behavior after impact event, detailing the consequences of the damage by analyzing factors such as the influence of specimen's geometry, energy and damage thresholds, type of fiber and resins, stacking sequence and boundary conditions, among others. A review of available literature shows dispersion in the results due mainly to the lack of methods standardized specifically for the impact testing of long fiber composites [10]. A recent standardized test to assess the impact tolerance (ASTM D7136 and D7137) has remedied partially the problem; impact and compression after impact apparatus, material for supports, specimen features, boundary conditions, striker material and geometry, etc. have been standardized [11, 12], but much work must still be done due to the costs and effort required for these tests.

Different non-destructive inspection techniques have been investigated by detecting the presence of internal damage. Ultrasonic and radiographic methods are by far the two most commonly used techniques [1, 4]. Both techniques provide a projected image of the damaged zone, allowing determining the extent of damage. Recent ultrasound equipment produces B and C-scan images, which provides through thickness damage information, size and orientation. Main disadvantages of these nondestructive techniques is that to inspect a whole structure, normal operations must be interrupted and sufficient time must be allowed for completed inspection. Vibration testing is recognized as an effective and fast method that has been shown to be able to detect various failures in a structural element, but also to characterize and localize the vicinity of the damage [13 - 21]. Measured change of the natural frequencies can be employed to identify damage such as delaminations and those related to the residual mechanical properties.

In the present paper, an extensive experimental investigation upon the influence of low velocity impact damage in carbon fiber laminated composites has been undertaken. The aim of this work is based upon the results 
of non-destructive techniques such as ultrasonic phased array or experimental modal analysis, to establish relations to assess the bearing capacity of laminated composite specimens that have suffered impact damage. The results of both destructive and non-destructive experiments carried out on forty-eight composite specimens are presented. The results of the ultimate strength obtained in compression test and changes of natural frequencies are related to the impact energy and delaminated area.

\section{Analytical approach}

In order to determine the effect by the presence of damage induced by low velocity impact upon the dynamic behavior and residual properties of a laminated composite plates, experimental modal analysis, ultrasonic inspection, impact testing ASTM D7136 [11] and compression after impact testing ASTM D7137 [12] have been conducted. Prior to each impact test, all specimens were inspected for manufacturing defects using ultrasonic B and C-scans inspection technique, and modal parameters were determined under free boundary conditions. To assess the compressive residual strength of specimens containing a specific damaged state, standard specimens have been subject to multiple low velocity impacts at various impact energy levels, ranging from 5 to 70 Joules. Following impact test, the projected area of the resultant delamination was measured and modal parameters were again determined. Finally, compression after impact testing in pristine and damaged plates was conducted. A relationship between impact energy versus the projected delaminated area and changes of natural frequencies versus ultimate strength can then be developed.

Assuming a harmonic motion, the natural vibration frequencies and the associated mode shapes of a homogeneous linear undamped system can be obtained by solving the generalized matrix eigenvalue problem, defined as

$$
\Omega[M \rrbracket \Phi]=[K \rrbracket[\Phi] \Rightarrow[[K]-\llbracket[\Omega \rrbracket[M][\Phi]]=0,
$$

where $[K]$ and $[M]$ are the global stiffness and mass matrices, respectively, $[\Omega]$ is a diagonal matrix listing the corresponding eigenvalues (natural vibration frequencies) and $[\Phi]$ is the eigenvector matrix (mode shapes). Apart from boundary conditions and applied forces, modal parameters (frequency and mode shapes) are characteristics of a plate's mass and stiffness. Damage is defined as changes to the material or geometric properties of a system that affect its system's performance. Considering the effect of impact induced delamination as a local damage whose influence on the stiffness of the material is established, it can be expected that such deterioration affects the natural frequencies and associated mode shapes. Quantitative relations between damage and the resulting changes in modal parameters can be developed from a perturbation of the equation of motion (Eq. 1). For the perturbed system, Eq.1 becomes

$$
[[K]+[\Delta]-[[\Omega]+[\Delta \Omega][[M][[\Phi]+[\Delta \Phi]]=0,
$$

where $[\Delta \Omega]$ and $[\Delta \Phi]$ are the variation of the natural frequencies and mode shapes, respectively, induced by
$[\Delta K]$. Given a non-zero eigenvector $\{\phi\}$, from the generalized Rayleigh quotient defined as

$$
R([K],[M],\{\Phi\})=\frac{\{\Phi\}^{T}[K]\{\Phi\}}{\{\Phi\}^{T}[M]\{\Phi\}}=\omega^{2},
$$

where $\omega^{2}$ is the natural vibration frequency, the effect of $[\Delta K]$ on a particular mode can be determined. Particularizing equation Eq. 3 for the $i^{\text {th }}$ natural frequency and associated $i^{\text {th }}$ mode shape, the generalized Rayleigh quotient can be expressed as

$$
\omega_{i}{ }^{2}-\Delta \omega_{i}{ }^{2}=\frac{\left.\left.\left\{\phi_{i}\right\}^{T}+\left\{\Delta \phi_{i}\right\}^{T}\right]+[[K]+[\Delta K]]\left[\phi_{i}\right]+\left[\Delta \phi_{i}\right]\right]}{\left.\left\{\phi_{i}\right\}^{T}+\left\{\Delta \phi_{i}\right\}^{T}\right]+[M]\left[\left[\phi_{i}\right]+\left[\Delta \phi_{i}\right]\right]}
$$

Because of the fact that $R([K],[M],\{\phi\})$ reaches the stationary value when $\{\phi\}$ is equal to the eigenvector $\left\{\phi_{i}\right\}$, Eq. 4 can be simplified as

$$
\Delta \omega_{i}^{2}=\left\{\phi_{i}\right\}^{T}[\Delta K]\left\{\phi_{i}\right\} .
$$

Eq. 5 indicates that a decrease in stiffness induced by the local damage causes a decrease in natural frequencies and vice versa. Intuitively a decrease in natural frequencies induced by the increase in impact energy can be expected, as shown in the following section.

\section{Experimental procedure}

\subsection{Test specimens}

The monolithic composite plates examined in this work are T300 carbon fibers in an epoxy matrix with a fiber volume fraction of $58 \%$. Its construction consists of a 40 unidirectional T300 carbon fiber reinforced epoxy plies with a symmetric stacking sequence $\left[45^{\circ} / 0^{\circ} /-45^{\circ} / 90^{\circ}\right]_{5 \mathrm{~S}}$, which achieve a total cured thickness near to $6 \mathrm{~mm}$ with a uniform cross-section over the entire surface. The laminated plate layup is defined such that the $0^{\circ}$ fiber orientation is aligned with the lengthwise dimension. The plates specimens had a size of $150 \times 100 \pm 0,25 \mathrm{~mm}$.

\subsection{Ultrasonic testing}

The term state of damage implies knowledge of the type extent and location of damage and is threedimensional in nature. Ultrasonic phased array testing provides a precise through thickness damage information useful for determining the depth, size and distribution of internal delaminations. The most widespread form of damage created during impact testing is delamination. Delaminations are critical in the subsequent post-impact compression strength of a composite plate, as discussed in the following sections. The extent of damage was determined after damaging event using non-destructive ultrasonic inspection equipment OmniScan MX with standard phased array probe $5 \mathrm{MHz}$ linear array 64 elements. Using data from C-scanner the extent of projected area of the resultant delamination was determined.

\subsection{Experimental modal analysis}

Experimental modal analysis is the process of determining the modal parameters (frequency, damping and mode shapes) of a linear time-invariant system. It is generally based upon a theoretical relationship between measured quantities, the so-called Frequency Response 
Function (FRF), and classical vibration theory represented as matrix differential equations of motion.

The test environment involves several factors that must be taken into consideration as the appropriate boundary conditions of the plates. To reproduce free boundary conditions in the laboratory several options exist: either the plate can be situated on an undulated foam surface, or it can be suspended either horizontally or vertically. For the present work, the various situations were tested and the results indicated a minimal difference; therefore, a vertical suspension was ultimately employed.

Among different testing configurations, tests were performed with a single-reference testing employing a roving hammer test. To measure a FRF of a structure basically two channels are needed: one channel is used to measure the excitation force and the other one to measure acceleration response of the plate. A stationary monoaxial accelerometer has been attached to a single degree of freedom (DoF) reference point whereas the hammer roved around exciting the specimen at well-distributed measurement DoF's.

The experiments were conducted using a Brüel \& Kjaer type 4518-003 uniaxial accelerometer, whose mass is less than $1,5 \mathrm{~g}$, along with a miniature transducer hammer Brüel \& Kjaer model 8204 for the excitation of the system. Due to the accelerometer being attached to the test specimen, there is a certain amount of mass that is added to the structure. It is important to assure that the mass of the transducer is negligible when compared with the effective modal mass of a mode of vibration so as not to interfere with the vibrational behavior. Both the applied excitation and the measured response were perpendicular to the plate. The range of frequencies studied was between 5 and $10000 \mathrm{~Hz}$ with a resolution of $0,125 \mathrm{~Hz}$. The data acquisition system was a Brüel \& Kjaer model 3050-B-6/0. An analysis of the measurements was performed using Brüel \& Kjaer PULSE v.14, and for the estimation parameters, the modal and structural analysis software ME'Scope VES ${ }^{\mathrm{TM}} 7754$ was employed. Fig. 1 shows the measurement set-up for modal testing.

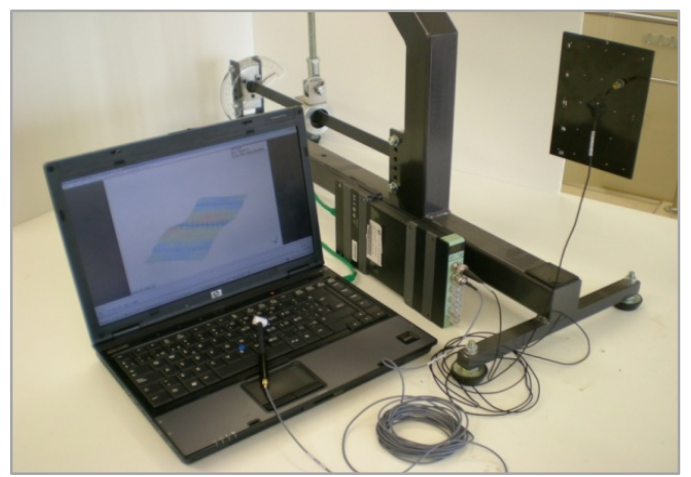

Fig. 1. Assembly made for modal testing

In order to have sufficient spatial distribution it is necessary to have a reasonable number of well-distributed DoF's measurement. While a larger number of finite matrix measurement points results in a higher description for the mode shape, because of time and cost constraints, the number of measured points was restricted to one 25 FRF's on each plate. The selection of the reference location is a critical step of performing an experimental modal test. If the accelerometer location is in a nodal position of a mode, FRF's may not contain strong response for this mode and consequently would be poorly represented or, in the worst case, completely absent. In the present work, any of the four points at the vertices has been found to be appropriate to place the accelerometer.

\subsection{Low velocity impact testing}

This test method determines the damage resistance of a multidirectional composite laminated plate subjected to a drop-weight impact event. The test equipment utilized in this work meets the requirements of the American Society for Testing and Materials outlined in the ASTM D7136 [11]. The rectangular specimen is subjected to an out-ofplane concentrated impact (perpendicular to the plane of the laminate) using a drop-weight device with a hemispherical striker tip with a diameter of $16 \pm 0,1 \mathrm{~mm}$ and a hardness of $60 \mathrm{HRC}$. The incident impact energy corresponds to the potential energy of the drop-weight, defined by the mass (2240 gr) and drop height of the impactor. The damage resistance is quantified in terms of the resulting size and type of damage in the specimen.

The specimen was placed in the rigid support fixture, centered relative to the cut-out and was secured in place using the four rubber-tipped clamps, positioned at $25 \mathrm{~mm}$ from the specimen edges, in order to prevent the specimen from rebounding during impact event. Figure 2 shows the drop-weight impact-testing device utilized. The impact device includes a rigid base, a cylindrical drop-weight impactor and a cylindrical guide mechanism. A rebound catcher is used to stop the impactor during its second descent.

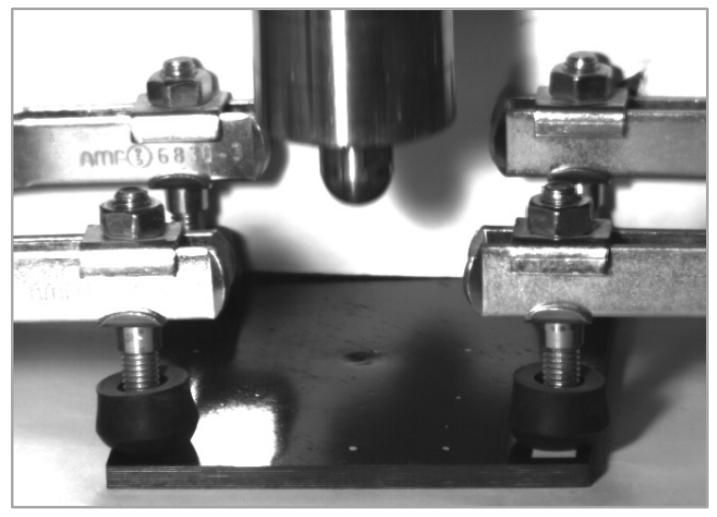

Fig. 2. Drop-weight impact-testing device utilized

Specimens have been subject to low velocity impacts at various impact energy levels, ranging from 5 to 70 Joules. At least two specimens have been tested per test condition. The form of impact scenario that has attracted most experimental study has been based on low velocity composite materials, due to its capability to significantly reducing residual performance of a composite structure even in the case where damage is barely visible. For that reason, incident energy has been limited to 70 Joules, value below the penetration threshold energy.

\subsection{Compression after impact}

This test method determines the residual strength of flat rectangular composite plate previously subjected to a damaging event (in accordance with test method ASTM D7136), which is tested under compressive loading using a 
stabilization fixture. The test equipment utilized in this work meets the requirements of the standard outlined in the ASTM D7137 [12]. The compressive test is undertaken in a multi-piece support fixture, which utilizes adjustable retention plates that provide no restraint to local out-ofplane rotation, to support the specimen edges and inhibit buckling when the plate is end-loaded. The top and bottom supports provide no clamp-up, but provide some rotational restraint due to the fixture geometry. The compressive residual strength support fixture is shown in Figure 3. It has been carefully aligned in order to minimize loading eccentricities and induced specimen bending.

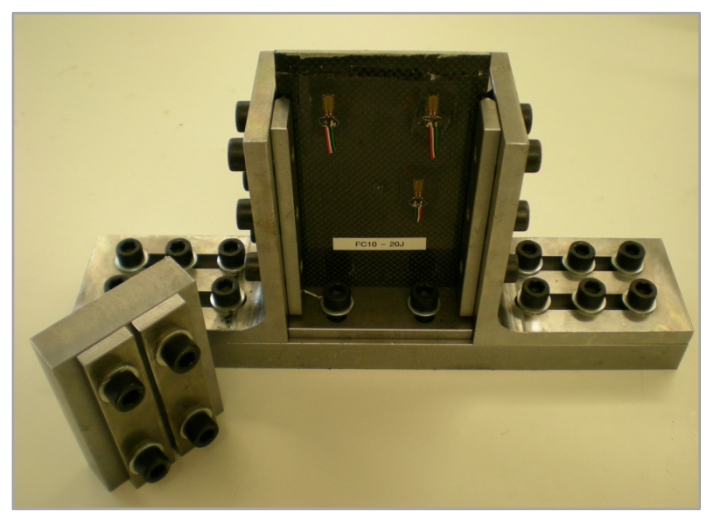

Fig. 3. Compressive residual strength support fixture with specimen in place

The specimens were compression loaded aligned with the lengthwise dimension. The plate is loaded with a crosshead displacement rate of $1,25 \mathrm{~mm} / \mathrm{min}$ until a maximum force is reached and then subsequently drops to around $25 \%$. The compressive force was applied using a MTS model $244.31250 \mathrm{kN}$ actuator. In order to ensure the application of pure compressive loading and to assess the presence of any bending or buckling at plate failure, strain measurement were performed in 12 plates. Longitudinal strain was measured simultaneously at five locations, two locations on opposite faces of the specimen and one in the neighborhood of the impact location in order to provide an estimate of surface strain at failure. Five strain gages HBM 1-LY41-6/350 were bonded to each instrumented plate. The average of the two back-to-back strain values was less than $5 \%$. Additionally out-of-plane displacement was measured using an inductive displacement transducer LVDT HBM WA20. As indicated in the standard, a rapid divergence of the strain readings on the opposite faces of the specimen or a rapid increase in percent bending are indicative of the onset of panel instability and consequently the plate is buckling and influencing the results. Force, crosshead displacement, out-of-plane displacement and strain data were recorded at $25 \mathrm{~Hz}$ sample rate. Data recording of the measurements was performed using MGCplus data acquisition system.

\section{Results}

Fig. 4 illustrates ultrasonic C-scan (left), showing the surface location and B-scan (right) indicating the depth damage of a specimen after $40 \mathrm{~J}$ impact. Delaminations occur at the interface of adjacent laminas. The C-Scan results prove that impacts generate oblong shapes radiating from the impact site with the major axis aligned with the fiber orientation. The superposition of these oblong delaminations is the ellipse represented in the left hand figure. Small discontinuities out of the damaged area are due to manufacturing defects. Through thickness damage information are illustrated by B-scan. Damage is characterized by a conical shape originated at the contact site. As can be seen, damaged area is significantly lower in those plies closer to the impact point. It should be note that if multiple delaminations are induced, ultrasonic scanning will only determine the depth and shape of the delamination closest to the surface.
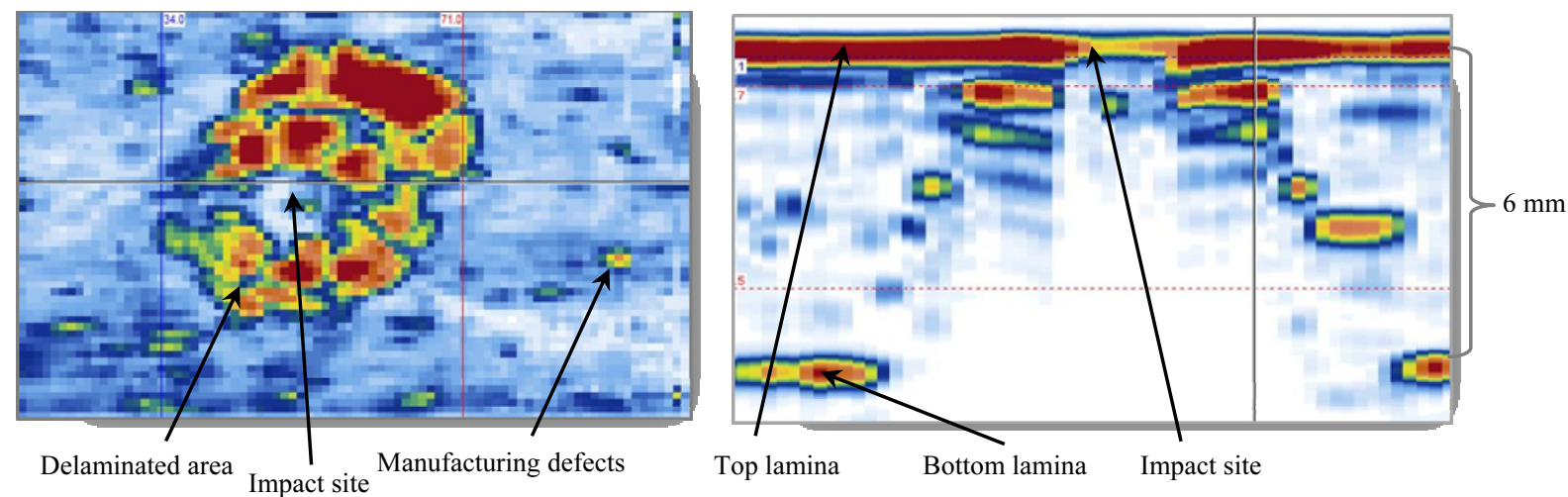

Fig. 4. Ultrasonic C-scan (left) and B-scan (right) of a specimen after $40 \mathrm{~J}$ impact.

Phased array results require image manipulation and assessment of contours to obtain the projected delamination area. In Fig 5, the damaged area as a function of an impact energy for each specimen has been represented. Inspection shows that below $15 \mathrm{~J}$, force for onset of delamination has not been achieved and consequently no damage has occurred. After threshold is reached, delamination area increases linearly with the impact energy. Increasement in damaged area can be attributed to the increasement in bending induced shear stresses. The change in trend beyond $50 \mathrm{~J}$ is supposedly due to the influence of the impact support structure.

Fig. 6 shows the compressive strength after impact as a function of impact energy. As can be seen, once the impact 
ISSN 1392-2114 ULTRAGARSAS (ULTRASOUND), Vol. 66, No. 2, 2011.

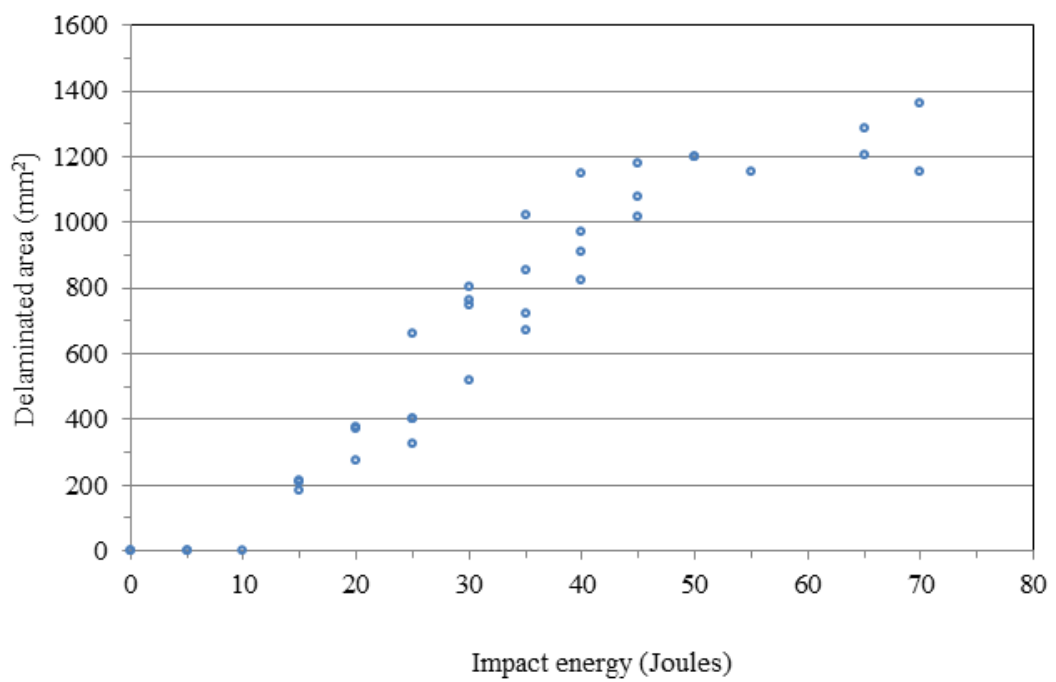

Fig. 5. Projected delamination area versus impact energy

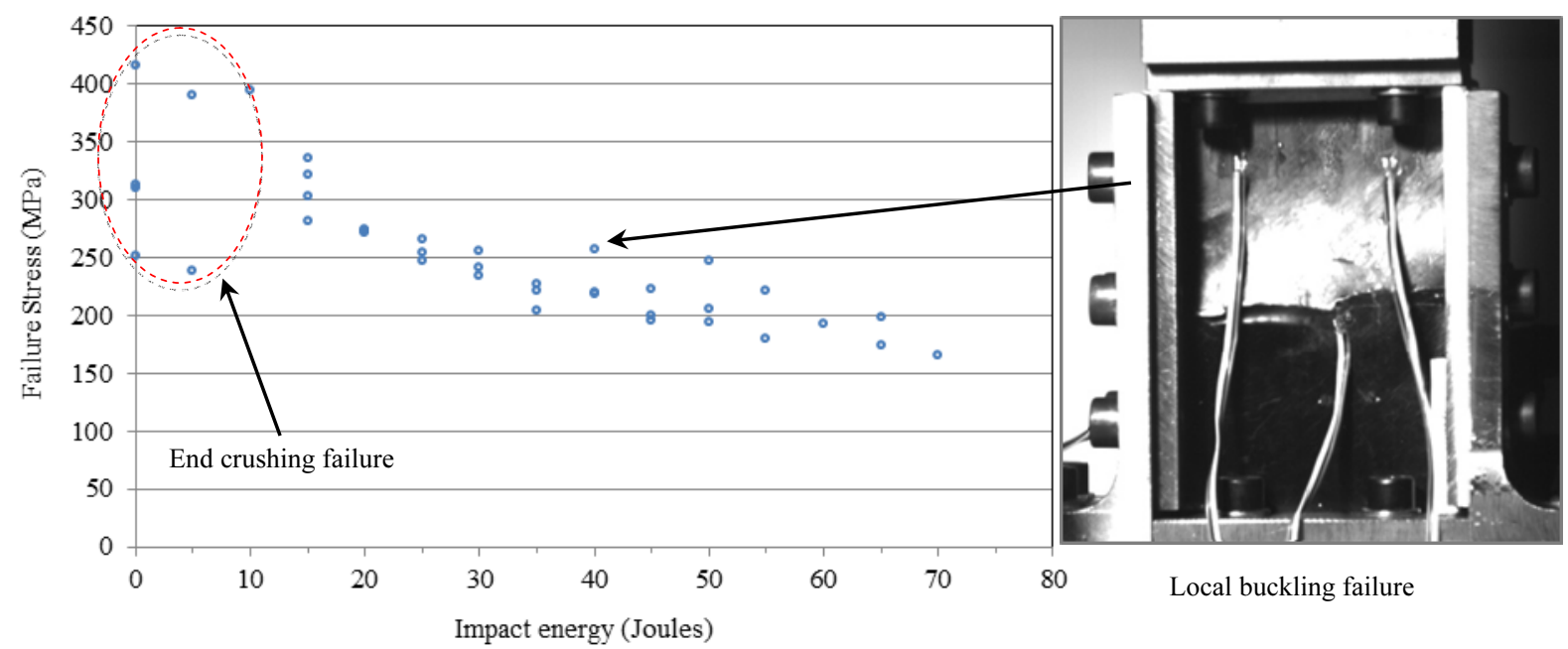

Fig. 6. Projected delamination area versus impact energy and local buckling failure with kink bands

energy exceeds the critical threshold, the compressive strength reduction is significant. An attempt was made to employ the support fixture to test undamaged specimens (below $15 \mathrm{~J}$ ), but such tests demonstrated a relatively high incidence of undesirable failure modes such as end crushing. The right hand figure illustrates an example of local buckling failure with kink bands, one of commonly acceptable compressive residual strength failure mode.

Fig. 7 represents relative changes of natural frequencies of the bending modes $\left(\begin{array}{lll}2 & 0\end{array}\right)$ and $\left(\begin{array}{ll}0 & 2\end{array}\right)$ as a function of impact energy under free boundary conditions. Mode's nomenclature $(\mathrm{m}, \mathrm{n})$ identifies the different mode types, where $m$ and $n$ refer to the number of nodal lines parallel to $y$ direction and $x$ direction, respectively. Although 10 modes were measured, only two of them are represented. As can be observed, results show a systematic decrease of natural frequencies with increasing impact energy. However, not all natural frequencies are equally affected by impact damages. The most significant variation is found in the higher modes or in which damaged areas are not located on a nodal line. Measuring higher modes requires a higher spatial discretization, which involves more time for testing. On the other hand, low modes have a major influence on the structural behavior.

Small increases of the natural frequencies for energies below $40 \mathrm{~J}$, is assumed due to local stiffening and experimentation errors. The sensitivity of the variation in frequency by impact damages can be seen from the $40 \mathrm{~J}$, which corresponds to a projected delaminated area of about $1000 \mathrm{~mm}^{2}$ and a reduction of compressive strength of more than $50 \%$.

\section{Concluding remarks}

Throughout a series of impact tests on carbon fiberreinforced specimens has been shown that low-velocity impacts induce significant internal damage, which causes large reductions on the compression strength of the laminated. Compressive strengths of pristine specimens have not been obtained, due to high incidence of undesirable failure modes such as end crushing. Other methods such as ASTM D6641 should be considered for this purpose. 

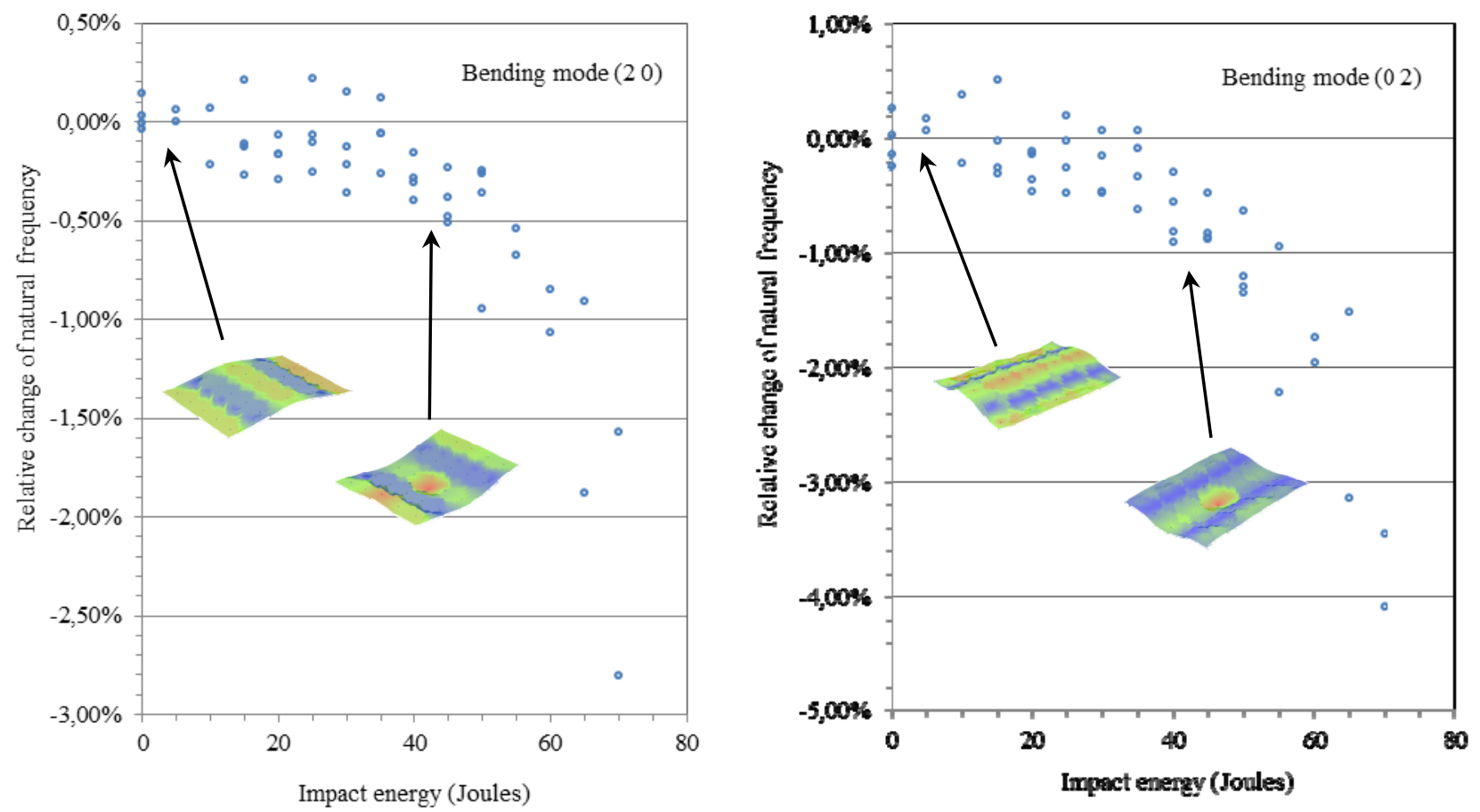

Fig. 7. Relative changes of natural frequencies of the bending modes (2 0$)$ and $\left(\begin{array}{l}0 \\ 2\end{array}\right)$ as a function of impact energy under free boundary conditions

The ultrasonic inspection equipment utilized in this work provides through thickness damage information in a practical and efficient way. A good correlation between incident impact energy and delaminated area is noticed. The main disadvantage is that to inspect a structure requires prior knowledge of the damage location; otherwise sufficient time must be allowed to complete the inspection. Moreover, the definition of the delamination boundary is subject to the operator interpretation, making it difficult to determine the damaged area objectively.

Vibration testing is an effective and fast method that shown to be able to detect impact damaged in composite plates, but also to characterize and locate the vicinity of the damage. Good agreement between measured changes of the natural frequencies and impact energy has been observed. As anticipated above, Eq. 5 indicates that a decrease in stiffness induced by the local damage causes a decrease in natural frequencies. The low sensitivity for low impact energies is presented as a distinct disadvantage. Despite this, its non-destructive nature, its relative simplicity and the possibility of automation by using piezoelectric sensors, makes it a potential alternative for impact damage detection.

Future lines of enquiry might be to analyze larger structures with continuous monitoring, and develop experimental-numerical methods for identification of damage and residual properties from dynamic parameters.

\section{Acknowledgement}

Most of the developments included in this work are consequence of several research Projects. The institutions and companies responsible of these Projects are gratefully acknowledged. These are the Spanish Government, through the Ministerio de Ciencia e Innovación (Grant No. UNPC08-4E-007, RECOMP Project, ref. BIA2005-06952 and DECOMAR Project, ref. MAT2003-08700-C03-02), and the Ministerio de Fomento (Project Retrofitting and reinforcement of reinforced concrete structures with composite materials. Numerical and experimental developments applied to joint of bars and composites anchorage proposal); AIRBUS through the Project FEMCOM and ACCIONA Infrastructures through the Project SPHERA. All this support is gratefully acknowledged.

\section{References}

1. Abrate S. Impact on composite structures. New York: Cambridge University Press. 1998. ISBN 0-521-01832-3.

2. Cantwell W. J., Morton J. The impact resistance of composite materials: a review. Composites. 1991. Vol. 22. No. 5. P. 347-362.

3. Richardson M. O. W., Wisheart M. J. Review of low-velocity impact properties of composites materials. Composites. Part A: Applied Science and Manufacturing. 1996. Vol. 27. No.12. P. 11231131.

4. Reid S. R., Zhou G. Impact behaviour of fibre-reinforced composite materials and structures. England: CRC Press. 2000. ISBN 0-84930847-X.

5. Martinez X., Rastellini F., Flores F., Oller S. and Oñate E. Computationally optimized formulation for the simulation of composite materials and delamination failures. Composites. Part B: Engineering. 2011. Vol. 42. P. 134-144.

6. Reis L. and De Freitas M. Damage growth analysis of low velocity impacted composite panels. Composite Structures. 1997. Vol.38(1-4). P. 509-515.

7. Schoeppner G. and Abrate S. Delamination threshold loads for low velocity impact on composite laminates. Composites. Part A. 2000. Vol. 31 (9). P. 903-915. 
8. Shyr T. W. and Pan Y. H. Impact resistance and damage characteristics of composite laminates. Composites Structures. 2003..Vol. 62. N. 2. P. 193-203.

9. Lopes C. S. et al. Low-velocity impact damage on dispersed stacking sequence laminates. Part I: Experiments. Composites Science and Technology. 2009. Vol. 69 (7-8). P. 926-936.

10. Sanchez-Saez S. et al. Compression after impact of thin composite laminates. Composites Science and Technology. 2005. Vol. 65 (13). P. 1911-1919.

11. ASTM D 7136/D 7136M 07 Standard Test Method for Measuring the Damage Resistance of a Fiber-Reinforced Polymer Matrix Composite to a Drop-Weight Impact Event. 2005.

12. ASTM D 7137/D 7137M 05 Standard Test Method for Compressive Residual Strength Properties of Damaged Polymer Matrix Composite Plates. 2005

13. Salawu O. S. Detection of structural damage through changes in frequency: a review. Engineering Structures. 1997. Vol. 19 (9). P.718-723.

14. Grady J. E., Meyn E. H. Vibration Testing of impact-damaged composite laminates. NASA. Technical Memorandum 4115. 1989.

15. Sanders D. R. et al. Nondestructive evaluation of damage in composite structures using modal parameters. Experimental Mechanics. 1992. Vol. 32 (3). P. 240-251.

16. Araujo dos Santos J. V. et al. Structural damage identification in laminated structures using FRF data. Composite Structures. (2005). Vol. 67 (2). P. 239-249.

17. Kessler S. S. et al. Damage detection in composite materials using frequency response methods. Composites. Part B. 2002. Vol. 33 (1). P. 87-95.

18. Penn L. S. et al. Use of the free vibration spectrum to detect delamination in thick composites. Journal of Composite Materials. 1999. Vol. 33 (1). P. 54
19. Zou Y. et al. Vibration-based model-dependent damage (delamination) identification and health monitoring for composite structures: a review. Journal of Sound and Vibration. 2000. Vol.230(2). P. 357-378

20. Yam L. H. et al. Nondestructive detection of internal delamination by vibration-based method for composite plates. Journal of Composite Materials. 2004. Vol. 38 (24). P. 2183.

21. Della C. N. and Shu D. Vibration of delaminated composite laminates: A review. Applied Mechanics Reviews. 2007. Vol. 60. P. 1.

M. A. Perez, L. Gil , S. Oller

Pažeidimo sluoksniuotuose anglies pluošto kompozituose sukelto mažo greičio smūgio įvertinimas neardomaisiais bandymais

Reziumè

Anglies pluošto kompozitai plačiai naudojami aviacijoje, transporto priemonèse ir ívairiose lengvose struktūrose. Dèl didelio stiprumo ir galimybès būti pritaikytiems ịvairiose konstrukcijose šie kompozitai turi didelị pranašumą, palyginti su tradicinèmis medžiagomis. Tačiau ju elgesys smūgio metu, kas gali įvykti gamybos, eksploatacijos ar profilaktikos salygomis, yra labai svarbu. Ši situacija ypač kritiška esant smūgiams, kurie sukelia vidinius pažeidimus nerandamus vizualinès inspekcijos metodais. Neardomųų bandymų metodai, pagrịsti ultragarsiniu faziniu gardeliu arba monoanalize, gali padèti papildomai ịvertinti pažeidimus ir struktūros vientisumą. Straipsnyje pateikti tiek ardomujų, tiek neardomujų bandymų rezultatai, gauti tiriant 48 kompozitu bandinius. Rasta gera koreliacija tarp smūgio energijos ir atsisluoksniavimo zonos ploto, be to, pastebèti savujų rezonansiniu dažnių pokyčiai.

Submitted 29042011 